\title{
The Role of Urban Forestry in Regional Landscape Design
}

\author{
H. E. Hirvonen
}

Lands Directorate, Atlantic Region

Environmental Management Service

Fisheries and Environment Canada

Halifax, Nova Scotia

\begin{abstract}
The urban forester has a vital role to play in the land use planning process of peri-urban regions, $\mathrm{He}$ gathers and synthesizes data on pertinent physical and biological parameters and integrates these parameters into workable units for interpretive purposes. A sound understanding and proper manipulation of naturally occurring vegetation can not only enhance the final regional design but serves as a valuable tool in the communicative process amongst the urban forester, land planner and the general populace. Experience gained in urban forestry programs undertaken in southwestern British Columbia, indicates that the manner of presentation of technical data is at least as important as the understanding of that data for landscape design purposes.
\end{abstract}

\section{Résumé}

L'ingénieur forestier spécialisé en foresterie urbaine doit remplir un rôle de premier plan dans l'utilisation des terres des régions péri-urbaines. II complète et synthétise les données pertinentes aux paramètres biophysiques et intègre ceux-ci en unités de travail pour fins d'interprétation. Une compréhension saine et une manipulation adéquate de la végétation naturelle peuvent non seulement donner plus de valeur au dispositif régional final mais servent davantage en tant qu'outil précieux dans les moyens de communication entre le forestier urbain, le responsable à la planification et la population en général.

L'expérience acquise dans de tels programmes encourus dans le sud-ouest de la Colombie britannique montre que la façon de présenter les données techniques s'avère tout aussi importante que la compréhension même de celles enregistrées dans un but de dispositif paysagiste.

\section{Introduction}

The terms urban forestry, amenity forestry, regional forestry and landscape forestry have appeared in literature with increasing frequency in recent years. What exactly is being described? Jorgensen (1970) has defined urban forestry thoroughly as a "specialized branch of forestry which has as its objective the cultivation and management of trees for their present and potential contribution to the physiological, sociological and economic well being of urban society. These contributions include the overall ameliorating effects of trees on their environment as well as their recreational and general amenity value."

Explicit in the above definition, is the point that the practice of urban forestry includes the management of the total forested landscape within the sphere of influence of urban centres. This encompasses not only trees but minor vegetation and the physical land characteristics as well. In essence, to manage trees properly one must properly manage the total landscape.

Thus, it is implicit that urban forestry is not restricted to management of only single tree species within city boundaries. The peri-urban landscape is also an integral part of urban forestry. This paper outlines the role that the urban forester can play in the regional planning process of such areas. Some benefits of maintaining as much vegetative cover as possible in urban and outlying areas are described. This is followed by an outline of constraints to blanket manipulation of naturally occurring vegetation. One practical application of urban forestry employed in sections of southwestern British Columbia is described to illustrate how the urban forester can best present his information to the planners before final land allocation decisions are made.

\section{The Urban Forester and Regional Planning}

The urban forester is not a land planner or an urban planner, yet his task is an integral part of the planning process. In urban-centred regions the land planner normally makes the land use allocation decisions. The role of the urban forester is to provide that planner with basic information on the landscape under study. $\mathrm{He}$ is the one that gathers, assimilates and synthesizes data on pertinent physical and biological parameters and integrates these parameters into workable units for interpretive purposes.

The urban forester may also be involved in such duties as town design or layout of regional parks once the land use allocation decisions are made. Such landscape designing is an important part of the urban forester's job. However, the packaging and presentation of the critical environmental parameters to the planner before the decisions are made remains as the crucial task. In the implementation of this task it is not an unfair bias to emphasize vegetation to describe these "packaged" units. The lay person more readily recognizes and identifies with the standing vegetation than with any description of underlying till or colluvium. The aim is to develop a common understanding of the local landscape amongst the planner, local populace and urban forester.

The responsibility still lies with the urban forester to compile and evaluate information on soils, landforms, geology, wildlife and other relevant data as well as vegetation. Once these data are integrated, the emphasis must be placed on presentation. Technical information can be extracted whenever needed to substantiate the response to a query.

\section{Beneficial Effects of Vegetation}

As stated above, descriptions of vegetation serve a valuable function in implicitly describing the complex interactions of the ecosystem to lay 
persons. The careful management of natural vegetation has benefits that are more wideranging. One obvious point to consider is that the plant community is a vital component of the ecosystem and to have sound ecological land use planning one must have sound vegetation management. A cross-section of the kinds of direct and indirect benefits that may be derived by maintenance of as much vegetative cover as feasible follows.

Air Pollution. Trees play a vital role as air filters and as "sinks" for certain gases and odours (Hill 1971). Tree-lined freeways and highways can go a long way in reducing automobile pollution. Certain tree species may absorb and assimilate polluted air better than others. There are even suggestions (Lebanidze 1971) that trees planted in cities should be chosen for their "clean-up" capability rather than for their growth rate and beauty. An interesting viewpoint but much research is still needed.

The condition of some tree species can be a visual indicator of toxic conditions because many species react with greater sensitivity to certain gases than does man (Hodge and Smith 1970, Taylor 1970). Ozone, for example causes tipburn of eastern white pine (Pine strobus L.) and chlorotic mottling on ponderosa pine (Pinus ponderosa Laws) at concentrations as low as 5 parts per 100 million.

The results of studies on PAN (peroxyacl nitrates), sulphur dioxide, fluorides and others indicate that some deleterious effects are recognizable. If your surrounding vegetation is mysteriously yellowing or obviously dying you may be observing the reaction of plants to poisoning.

Noise Abatement. Many studies, particularly in the United States, indicate that trees are suitable as buffers for traffic, logging and other industrial noise (Cook and Van Haverbeke 1971, 1974. Aylor 1972). Deciduous species are less desirable than evergreens where a year-round noise foliage buffer is needed. When utilized as greenbelts, buffer zones often enhance the aesthetic quality of a region. Proper manipulation of the forested landscape can separate an industrial complex from an adjoining residential area both visually and aurally. As well, the multipurpose aspect of buffer zones for windbreaks, firebreaks, wildlife shelter and recreational pursuits must be valued.

Biological and Physical Control. Forest communities are an integral part of the regional ecosystem. They provide shelter and food to wildlife, prevent erosion of hillsides and stabilize river banks, maintain a certain equilibrium of the water table of an area and significantly influence regional and local climatic patterns. Jorgensen (1970) indicates "that the removal of tree cover from ravines, for example, may lead to increased speed of air drainage and cause climate changes above the ravine as well as in it."

Forests play a vital role in governing water quality. A reliable supply of unpolluted water throughout the year is essential for community stability. In areas of British Columbia, such as the Gulf Islands where available fresh water is at a premium, studies are now under way to search out the best means of preserving the small watersheds that do exist while still allowing for controlled residential growth. Landscape design is an integral part of the overall approach to this problem.

Wood and Fibre Production. Wood and fibre production cannot be ignored and, if properly managed, logging can become an integral and viable component of the peri-urban landscape as in many European countries. With recent innovations in both silviculture and woodlot management techniques, many farmers are beginning to realize the potential economic returns of planting seedlings. It has also been found that properly planned and presented logging operations may serve as valuable educational aids to the general public. The Lake Cowichan Valley Road Demonstration project north of Victoria, British Columbia is a good example of how the general public can become informed about the various planning stages of a managed forest (Crown, personal communication). This project and others like it have gone a long way in fostering a relationship of mutual trust between the forester and the public.

In essence, the productive capacity of a site in terms of wood and fibre, wildlife and the many intangible social values is directly related to the quality of management that site receives. A shortsighted engineer considering only the land base or a narrowminded forester recognizing nothing more than the wood fibre value of a site is directing himself headlong into a relentless and, most certainly, losing battle with nature.

Amenity Values. The opportunity must exist for the urban population to move easily to markedly different physical surroundings. As expected, not all of the population exercises the opportunity but it must be available. When the need for a change does arise most of us cannot venture too far to search it out. Thus, forested parklands or natural areas near major urban concentrations are a major factor in the social development of a city.

What types of forested landscapes are most aesthetically pleasing and suited for outdoor recreational activities? Because there are many subjective viewpoints one solution may be to strive for as much diversity of landscape as possible. Variety is consistently preferred over uniformity.

\section{Landscape Design}

The foregoing points illustrate the rationale behind sound urban or landscape forestry. A properly designed community that is structured in harmony with the landscape has many economic advantages over conventionally designed communities based on the right angle. These cost savings include: less clearing and grubbing of trees and shrubs, less grading to prepare for road and home construction, less road construction and shorter utility networks. (White, D. S. and E. J. Kress 1972).

Intangible benefits, although impossible to convert to monetary terms, are very real and important just the same. The preservation of vegeta- 
tion, in itself, leads to a sense of "oneness" within the community. Each community can have its own design suited to its own landscape which may be distinctly different from that of an adjoining community. In ecological design the basic tools may be the same, but the end product is always somewhat different. Each community develops a sense of individuality, yet this individuality in turn enforces a sense of regional unity.

Constraints of Vegetative Manipulation. The design of a residential or industrial complex should be developed in consideration of some basic guidelines in vegetative manipulation. These include:

1. Trees and minor vegetation are a major factor in stability of slopes. Their disturbance may lead to erosion.

2. Vegetation, once removed from areas where bedrock is close to the surface, is extremely difficult to re-establish and maintain.

Trees do not readily accept sudden major changes in groundwater level, or sudden exposure to sun, nor do they tolerate soil compaction or fill covering the root system (Jorgensen 1970).

政. The existing species on any particular site need o not necessarily be the most suited or the most on desirous species for that site. Present stands are directly related to past and present disaturbances which may or may not be allowed to ocontinue into the future.

S. Stands of trees cannot be considered in isolaहG. Thion. They must be considered as parts of an inE terrelated landscape. A change in one part of Wthe system will necessarily cause compensaotory adjustment to occur elsewhere within that (IIIsystem.

Stands should be checked to see if they are dominated by species prone to windfall or injury which may lead to disease or decay.

Diversity should be a goal. A concerted effort in maintaining a variety of natural vegetation not only enhances aesthetic appeal but reduces the impact of a disease outbreak on any single tree species.

A Landscape Analysis. As stated earlier, urban forestry involves much more than the cosmetic Faspects of landsape design. The urban forester's input into the planning process is vital before the actual land use allocations are made. How can this input be best applied? A brief mention of one approach utilized for the Gulf Islands area of southwest British Columbia may offer some assistance.

For the Gulf Lslands and southern Vancouver Island of British Columbia "landscape units" have been developed in conjunction with local planners and residents (Hirvonen 1976, Eis and Oswald 1975, Hirvonen, Senyk and Oswald 1974). In essence, these landscape units are composite units which integrate available information on geology, topography, climate, soils, hydrology and plant and animal ecology and express relative similarity and homogeneity. Although the resultant maps and accompanying reports represent the end products of a great deal of synthesis of technical data, these maps and reports are presented with a minimum of technical language. Jargon such as climax species, ortho humo-ferric podzol, shrinkswell ratio and biogeoclimatic sub-zone tend to obscure rather than clarify the substance of the landscape analysis.

The purpose of the landscape analysis was to provide the planners and their advisory boards with background data to aid the planning process. The responsibility of superimposing the various environmental factors presented with relevant social and economic considerations was left to them.

A detailed methodology of the analysis procedure is beyond the scope of this paper, however, one consideration that surfaced repeatedly deserves emphasis; community involvement is a necessity during the compilation and synthesis of field data. A day in the field with concerned planners and residents increases the acceptability of the final document substantially. Individuals who are concerned about the environment are anxious to contribute to the planning process and become involved readily. The urban forester must take advantage of ideas that evolve from such input.

Urban forestry involves not much more than a basic understanding of the natural landscape and of how the standing vegetation reflects this landscape. An important aspect of the urban forester's role lies in the synthesis and interpretation of technical data in a form comprehensible by the wide variety of people involved in the planning process. If this is accomplished, the complexities of land use planning have been certainly reduced for all concerned.

\section{References}

Aylor, D. 1972. Noise reduction by vegetation and ground. Accoustical Soc. Amer. J. 51(1): 196-205

Cook, D. I. and D. F. Van Haverbeke. 1971. Trees and shrubs for noise abatement. USDA Forest Serv. Res. Bull. No. 246

Cook, D. I. and D. F., Van Haverbeke. 1974. Tree covered landforms for noise control. USDA Forest Serv. Res. Bull. No. 263

Eis, S. and E. T. Oswald. 1975. The Highland landscape Canadian Forestry Serv. Pacific Forest Res. Centre Rep. Bc-X-119, Victoria, B.C.

Hill, A. C. 1971. Vegetation: a sink for atmospheric pollutants, Air pollut. Contr. Ass. J. 21(6) $=341-346$

Hirvonen, H. E. 1976. Bowen Island: as landscape analysis. Canadian Forestry Serv. Pacific Forest Res. Centre Rep. BC-X-122. Victoria, B.C.

Hirvonen, H. E., J. P. Senyk and E. T. Oswald. 1974 Saltspring Island: a landscape analysis. Canadian Forestry Serv. Pacific Forest Res. Centre Rep. BC-X-99. Victoria, B.C.

Hodge, H. C. and F. A. Smith. 1970. Air quality criteria for the effects of fluorides on man. Air Pollut. Contr. Ass. J. 20(4): 226-232

Jorgensen, E. 1970. Urban forestry in Canada. Fac. Forest, Univ. Toronto, Toronto.

Lebanidze, G. 1971. Which trees purify air? Curr. Dig. Soviet Press 23(5)

Taylor, C. O. 1970. Vegetation and air pollution. Impact of Air Pollution on Vegetation Conference April 7-9, 1970, Toronto.

White, D. J. and E. J. Kresse. 1972. Planning to save natural resources in residential development. J. Soil and Water Conserv. (July-August) 152-155 